\title{
Understanding the Bolivarian Revolution from Below
}

"We were sitting at home watching Chávez on TV when he gave the famous por ahora speech," Rosa, a staunch Chávez's supporter from Catia, recalled. "Afterwards, I said: 'there is our future president." " As we learned in the previous chapter, Chávez had led an unsuccessful military uprising against the government of Carlos Andrés Pérez (Acción Democrática) in February 1992. After the arrest, he was allowed to speak on national TV. Wearing his red signature beret, he was cast into the spotlight of Venezuelan public life, becoming a popular hero for large parts of the population. The words por ahora (for now) signaled that the fight against the then loathed political status quo was not over, and that Chávez could be the man leading that fight. Moreover, having for long been accustomed to politicians that lied and deceived, ${ }^{1}$ the population finally saw a man who was willing to take responsibility for his actions. A poem, handed to him in jail by an anonymous supporter, illustrates the sentiments that he incited in people at the time:

Our Chávez who is in jail

holy be thy coup

come (to revenge) to us, your people

make your will come through

that of Venezuela

that of your army

give us today the confidence already lost

and don't forgive the traitors

as we will neither forgive

(C) The Author(s) 2017 
those who apprehended you.

Save us from all the corruption, and liberate us from Carlos Andrés Pérez.

Amen.

(Elizalde and Baez 2004:9, author's translation from Spanish)

Six years later after his imprisonment, Chávez would move into the presidential palace Miraflores, sustained by a wave of popular support.

\section{SHIFTING THE LENS}

Many scholarly analysis and media accounts focus on the "gravitational power" that Chávez's figure exercised, some of them with an explicit undertone that portrays his supporters as passive and ignorant recipients of a seductive political message (e.g., see Corrales 2001; Canache 2002). However, in this and the following chapter, I will explore Chávez's appeal by turning my attention away from his public persona for a while. That does not imply that I want to remove Chávez from my analysis; rather I posit that we have to slightly shift our perspective. If we focus too much on Chávez as a charismatic figure and ideologue, we miss the opportunity to appreciate the "thick background," to paraphrase Geertz (1973), which preceded and prepared the ground for people's support of the successive Chávez governments. In my analysis I will therefore focus on the shared historical experiences of marginalization and collective struggle that people from the popular sectors perceived as the background for embracing Chávez's political project. We will then be better equipped, I believe, to turn our attention back to Chávez's persona and understand how he was able to incite such popular support.

However, before we proceed, it is necessary to dwell a bit on the recurring classification of Chávez as a populist. Populism as a concept has been closely associated with Latin American politics though it has, in recent years, also been used to explain new political movements in Europe, the former Soviet Union and even contemporary US politics. Populism as a political style is generally understood to have surged in Latin America from the 1930s to the 1950s, supporting import-substitution industrialization (Weyland 1999:379) and gaining support from the working class. Examples of politicians embracing this approach are Juan Perón in Argentina, Lázaro Cárdenas in Mexico and Jorge Eliécer Gaitán (who was murdered) in Colombia. In more recent times, political leaders combining 
popular mass appeal with neoliberal policies have frequently been described as neopopulists (Ellner 2003). Examples are Alberto Fujimori in Peru, Fernando Collor in Brazil and Carlos Menem in Argentina.

However, the term "populism" itself remains highly contentious among researchers. As Jansen (2011) states, even academic discussions about the concept rely on folk theories (Jansen 2011:76). Indeed, "every usage of the term is overly general, applying to any person, movement, or regime that makes claims by appealing to ordinary (i.e., non-elite) people" (Jansen 2011:76). Several scholars have questioned the usefulness of the concept, though there have been a number of attempts to define and operationalize it for comparative analysis (Knight 1998; Weyland 2001; Roberts 2006; Jansen 2011).

\section{The Faceless Masses}

The purpose here is not to assess whether Chávez was a populist or not. In the descriptive and reductionist sense, or what we can summarize as "the political mobilization of mass constituencies by personalistic leaders who challenge established elites" (Roberts 2006:127), he certainly was, and it is beyond the scope of this book to engage in a discussion about populism as a concept. ${ }^{2}$ However, I do want to dwell a bit on what the labeling of Hugo Chávez as a populist entails in qualitative terms. There frequently is an inherent normativity in the use of the term "populist" which tends to lean toward describing a pathological trait of political culture, "to imply that the accused is corrupt, undemocratic, or cynically opportunistic" (Jansen 2011:77). This implicitly converts populism, as a concept, into a powerful weapon for discrediting political movements that appeal to the disadvantaged classes rather than to middle- and upper-class sectors. ${ }^{3}$ Populism becomes a catch-all phrase for a political form of advocacy for the rights and identity politics of certain sectors of the population. Obscuring the class politics in it, such an approach conveniently isolate and limit a political movement to a form or a relationship, without taking into account the historical context, or broader relations of power and domination circumscribing the political and social domain at large.

This use of the term is exacerbated by the fact that the concept belongs more to the realm of comparative politics and political sciences than to that of anthropology and ethnographically oriented sociology. This disciplinary dominance tends to produce an analysis that portrays "the masses" as a "faceless mass," responding in an instrumental way to the strategic 
maneuvers of a charismatic leader. Thus, the political agency of the electorate responding to this "populist call" and the relational and interpretative space between leaders and their supporters tend to be left as an explanatory open void.

It is precisely this void that I want to explore in this chapter, by focusing on people's own agency for engaging with the Bolivarian process, and their own historical experiences that sustain the world view and political alternatives that Chávez sketched out. Arditi (2007) has argued that populism is liberal democracy's "awkward guest": one which we seek to ignore, but which is nevertheless intrinsic to liberal democracies' entrenched shortcomings (Arditi 2007:78). "[Populism] is a symptom of democratic politics; it grants visibility to the founding negativity of the political by summoning the disruptive 'noise' of the people" (2007:78). In this view, populism is therefore a mirror to liberal democracy; it makes visible the claims and voices of those who are disenfranchised or muted within liberal democracy's architecture of power and privilege. This also explains why populism is so uncomfortable for the mainstream polity; it reminds us of how liberal democracy's idea of equal rights co-exists with the de facto unequal consummation of those rights.

If we adhere to the view that Chávez was a populist in the conventional, descriptive usage of the term, we may also read the evolvement of the Bolivarian popular process as a historical, context-specific reaction to how the particular architecture of liberal democracy in Venezuela marginalized large parts of the populace, both materially and identity-wise. This view frames the Bolivarian process as a political populist alternative where the "disruptive noise" of the people was finally forcefully heard and given a political space. It is impossible to properly understand the Bolivarian process without understanding its supporters' previous experiences with Venezuela's elite-controlled liberal democracy, and how they juxtaposed this epoch with Chávez's political message and project. The disruptive noise of the people had been present for a long time in Venezuelan society, only to be met with violence and censorship.

\section{A History of Popular Organization}

"Are you a Chavista as well?" I asked the feisty retired school teacher from 23 de Enero. She looked at me over the glasses in a typical teacher manner. "I have always been a revolutionary, and now I am a Chavista. And we will defend him to wherever, sick or not." This was said when 
Chávez had undergone his third cancer surgery in Havana in December 2012. "We will stand by him through whatever, unless he turns against el pueblo. Then..." she said, indicating that people's loyalty was dependent on Chávez's loyalty to the people who brought him to power. "But he would never do that," she said, convinced.

Social struggle in Venezuela didn't begin with the figure of Chávez. The popular sectors in Venezuela come from a long process of political and social resistance that multiplied, expanded and took on a new form when Chávez emerged on the national political scene. The variety of movements and networks supporting the Bolivarian project were highly heterogeneous in form as well as in focus. They were composed of a variety of activists, old and new, and a wide range of organizations, networks and groups with different genesis and organizational characteristics.

Contemporary urban movements trace their genealogy through four decades starting in the 1950s (Fernandes 2010:40). The 1950s were characterized by clandestine resistance to the authoritarian regimes, culminating with the overthrow of Marcos Pérez Jiménez in 1958. The following decade was dominated by guerrilla struggles brought about by the political exclusion of the left following the Pact of Punto Fijo. The 1970s were characterized by a surge of cultural activism, merging political activism with a wealth of cultural expressions among the popular sectors. The escalating socio-economic crisis of the 1980s generated a new wave of popularized resistance and public protest which, as we will see below, became increasingly violently repressed.

\section{0s: The Guerrilla Strategy}

Radicals from the Partido Comunista de Venezuela (PCV) as well as from Acción Democrática played a crucial role in bringing the dictator Marcos Pérez Jiménez down in 1958. From the 1940s onward, both parties built their support base on the popular sectors (Fernandes 2010:44). However, both PCV and the new radical party Movimiento de Izquierda Revolucionaria $(\mathrm{MIR})^{4}$ became excluded from formal political participation under the government of Rómulo Betancourt (1959-1964). Inspired by the Cuban revolution and deprived of other democratic channels, this political exclusion gave birth to a guerrilla movement that organized itself in small rural guerrilla units known as focos (Ciccariello-Maher 2013:32). The rural guerrilla units were also linked to networks in the popular urban neighborhoods, where they found food, shelter and storage for their 
weapons. This also made the popular neighborhoods and members of the excluded political parties a target of state repression.

The guerrilla movement was violently repressed by the state. Clashes happened all over the country, and most of the first guerrilla members were killed at an early stage (Ciccariello-Maher 2013:32). The political protest of students, peasants and workers was also met with state violence during the early Betancourt years. Ciccariello-Maher quotes a senior citizen who moved to Caracas in 1956: "The Betancourt years were the worst! It was lead, lead and more lead! His policy was to shoot first and ask questions later" (Ciccariello-Maher 2013:27).

The guerrilla conflicts waned down toward the end of the 1960s due to the progressive liquidation of combatants by state forces, tactical errors and internal rivalries (Ciccariello-Maher 2013). The decline of the guerrilla movement was also partly related to the so-called pacification strategy put in motion by Rafael Caldera (COPEI) when he gained the presidency in 1969 (Fernandes 2010:49).

Moreover, the guerrilla members increasingly found themselves without popular mass support (Ciccariello-Maher 2013). In the following decade, radical political parties growing out of the guerrilla struggle such as PRV (Party of the Venezuelan Revolution) and MAS (Movement for Socialism) would become important arenas for developing a "Venezuelan political radicalism," uniting "reformed guerrilla members" and new nascent political radicals. Urban struggle developed on various fronts (Ciccariello-Maher 2013:47), creating a radical current of leftist intellectuals, workers, students, cultural activist and other popular sector leftist networks and organizations. What remained of the guerrilla groups operated on both an open electoral and a clandestine front (Ciccariello-Maher 2013:65). Facing a "zealously repressive state apparatus" (CiccarielloMaher 2013:64), the legal fronts focused on organizing students and workers in mass protests, while also publishing radical newspapers. However, these "backroom" guerrilla groups lost legitimacy and failed to garner mass support, in particular after the high-profile kidnapping of an American businessman, referred to as the Niehous case (Ciccariello-Maher 2013:59-64). This kidnapping case also led to the arrest of some 400 revolutionary leaders. Many of the militants were also killed, further eroding the support base of what was left of the post-guerrilla organizations (Ciccariello-Maher 2013:61).

State-sponsored political mobilization was channeled through the clientelist apparatus of Acción Democrática at the time, which tapped into 
the popular sectors through a vast network of local neighborhood committees, including comités de barrio (barrio committees) and comités de base (base committees) (Fernandes 2010:46). Edgardo Lander describes this system as having a "populist-paternalist-clientelist character" (Fernandes 2010:46), creating a strong dependency on the state and weakening horizontal bonds in the community (Fernandes 2010:46). Constituting a threat to this mode of social control, the police would raid the popular neighborhood, looking for those considered insurgent and subversive.

Even though the guerrilla strategy never obtained mass support, these early forms of popular urban resistance played a central role in fomenting counter-hegemonic currents of resistance. Many of the activists I spoke to recall that their parents or relatives were politically active at the time. Thus, in spite of the evident guerrilla failure in terms of accomplishing revolutionary goals, this political epoch had a formative effect in shaping social and political consciousness in the barrios, providing a narrative of struggle that strongly informed political agency and ideology from below in the Chávez era.

\section{0s: The Cultural Turn}

While some continued to organize political parties and fronts, others turned to cultural politics during the 1970s (Fernandes 2010:49). This shift partly reflected a de-politization of the left, while cultural politics were incorporated into wider social and political struggle against the marginalization of popular sector neighborhoods (Fernandes 2010:49). Simultaneously, worker priests, formed by liberation theology, played an important role in mobilizing local communities against deficiencies in the health, education and infrastructure systems. The most important figure was the Belgian priest, Francisco Wuytack, based in the community of La Vega in western Caracas. He was deported by President Rafael Caldera in the 1970s, accused of interfering with internal politics and fomenting illegal street demonstrations (Fernandes 2010:51). However, Wuytack left an important legacy of mobilization and political consciousness that to this day makes La Vega one of the most politically vocal neighborhoods in Caracas (see Strønen 2006; Fernandes 2010).

In 23 de Enero, a new form of community activism also took shape, focusing on sports, cultural and social work. That is however not to say that that these activities were void of political content, or that the former political networks of the 1960s had disappeared. Rather, the new 
community organizations represented a new strategy for popularizing political ideas. This intertwining of culture and politics was highlighted by Ernesto, my host while I lived in 23 de Enero. He is now in his 60 s but has lived in 23 de Enero and participated in popular struggles since his youth:

[During other events] or the Holy Week we carried out activities that were related to religion, but also connected to another element, that of protest, the struggle. And of course all these things, as we now perfectly know, were monitored by the Venezuelan state and by its security organs. In the case of cultural and sports activities, these were a possibility we can say, a valve, that one could use for capturing people, in this case youths ... and be able to communicate a message as well, try to bring forward what one thought was best.

Moreover, protests and confrontation with state forces continued, and the focal point for struggle was the deficiency in basic infrastructures and services in the community. The 1970s were also marked by the ascendance of several significant popular folk singers who combined their artistic expressions with political activism, such as Grupo Madera and Ali Primera. Several of the members of Grupo Madera died in a boat accident in 1980, in what many believed was a "deliberate act of negligence on the part of the government" (Fernandes 2010:56). Ali Primera died in 1985, in what many people still today think was a rigged car accident.

\section{0s: The Battle Is in the Streets}

The 1980s saw the intensification of a direct and open conflict between the popular sectors and the state. The social control exercised by Accion Democrática through its paternalistic-clientelistic maneuvers waned as a result of multiple causes: a general economic decline and rise in poverty and unemployment rates, as well as the de-legitimization of the political parties and entities attached to it, such as the worker's union and neighborhood committees. Acción Democrática's growing inability to contain social activism through the continuation of clientelism and patronage meant that a new and broader field of social protest was opened up. Several and interrelated fronts of activism emerged.

Of central importance are the neighborhood or community movements, which have a long history in Venezuela (Rivero Santos 1995). Roughly speaking, neighborhood movements can be divided into two 
different organizational categories (López et al. 2002:63). As we just learned, popular sector demands were channeled through the clientelistic apparatus of Acción Democrática in exchange for electoral support. In the upscale neighborhoods on the other hand, community organizations exercised pressure on municipal authorities in order to tackle existing challenges in their urbanizations ${ }^{5}$ (Lopez et al. 2002:63). However, as the political ties between the popular sectors and the traditional political parties became weaker, neighborhood associations in the popular sectors increasingly started to stage street protests targeted at local authorities. This shift was also related to de-centralization reforms carried out in the 1980s, which transferred decision-making power and resources to local governments, while also reinforcing the segregation of neighborhoods with a strong or weak tax base (Fernandes 2010:58-59). The combination of impetus from the cultural politics of the previous decade and focus on local challenges consolidated a new form of activist identity and political thinking rooted in local communities (Fernandes 2010:59-60).

Street protests, where students played a central role, became a frequent form of protest from the 1980s onward, starting with the government of Jaime Lusinchi (1984-1989) (Lopez et al. 2002:13). The student movement has a long and vibrant history dating back to the nineteenth century (Lopez et al. 2002:148). Student protests frequently took the form of socalled encapuchados- masked protestors carrying out violent actions such as burning tires, barricading streets and throwing stones and Molotov cocktails. The students not only protested against the increasing deterioration of the quality of education, educational facilities, and student support, but they also became of central importance in organizing protests against the deterioration of living conditions in the popular sectors. During the 1980s, the student movement became the main target of state repression and many students were killed (Amnesty International 1980).

The 1980s also gave birth to the so-called colectivos, mainly located in 23 de Enero (see Chap. 5). These radical, often armed, groups emerged not only as a response to the increasing incursion of drug trafficking and crime in popular sector communities, but also as a response to the violent practices of state forces. Indeed, many people viewed drug trafficking and police abuse as two sides of the same coin, as the police was allegedly central in masterminding drug trafficking in popular sector neighborhoods, seeking to undermine social cohesion and popular organization.

"Street politics" is the term that López et al. (2002) use to describe the increasing practice of street demonstrations taking place in Caracas during 
the 1980s and 1990s. These represented a "peculiar form of relation and negotiation between diverse social sectors and power" (López et al. 2002:9). Protests not only became more commonplace, but their nature was also more confrontational and aggressive. Moreover, new members of the society that hitherto had not participated in social protests, such as retirees, also went to the streets. These new modalities of social protest evidenced a shift in the relations between society and the agents of power (Lopez et al. 2002:10). The apparent social pact between Acción Democrática and sectors of the working class was shattered. In the absence of any other arena for articulating political demands, people increasingly took to the streets to voice their demands. The state responded with violent repression of a social sector that was increasingly vilified among the dominant sectors of society.

Finally, it is important to remark that the emergence of these forms of street protest and tentative organization around rights-based demands in Venezuela from the late 1980s coincided with similar trends across Latin America, coupled with a global tendency to frame citizenship around the notion of "rights." The increasing deprivation of conditions for social reproduction constituted a key mobilizational platform for these demands, as did the struggles for broadening "sociopolitical citizenship" (Escobar and Alvarez 1992:4), making identity struggles and claims for alternative spaces for political deliberation key foci for activism. Thus, in tracing the genealogy of popular mobilization in Venezuela, we can find a pattern of similar trends across the continent. In broad term, the foci of struggle shifted from the targeted criminalization and persecution of the left under the banner of the war against communism during the Cold War, to the increasingly broadening struggle between the state and a variety of social forces demanding basic rights and recognition (see Escobar and Alvarez 1992; Alvarez et al. 1998).

\section{The Hostile State: Memories from the Fourth REPUBLIC}

In his song "Alberto Lovera hermano," the popular folk singer Ali Primera commemorates Alberto Lovera, a teacher, leftist activist and secretary general of the Venezuelan Communist Party (PCV) who was kidnapped, tortured and killed by Venezuelan security forces in Caracas on October 17, 1965. 
You came out of the water in chains

Accusing, those who killed you

Your clamour is always heard

Revolutionary clamor

Your clamour is always heard

Alberto Lovera brother

They wanted, they wanted to hide your body

They tried, they tried to drown your clamour

Your clamour is always heard

Accusing, accusing

Your clamour is always heard

Alberto Lovera brother

And it is the clamour of your people

The clamour of your beloved fatherland

Alberto Lovera brother

Your death will be revenged

Alberto Lovera brother

Your death will be revenged

$(\ldots)^{6}$

Lovera's body, wrapped in metal chains, got caught in a fisherman's net in the coastal state of Anzoátegui ten days later. Lovera's face, fingers and teeth had been crushed to complicate the identification process.

Albero Lovera was far from being the only prominent political activist who died by the hands of the police and security forces during the Punto Fijo period. Other high-profile victims include Fabricio Ojeda, the leader of the Patriotic Junta that overthrew the dictator Marcos Pérez Jiménez, and Jorge Rodriguez, the founder and secretary general of the political movement and party, Liga Socialista. Other particularly notorious episodes from the Puntofijo period include the Massacre of El Amparo in the state of Apure in 1988, where 14 fishermen were shot from behind and later presented as Colombian rebels killed in combat by Venezuelan security forces. Six years earlier, 23 members of a guerrilla cell from the radical underground movement of Bandera Roja (a political party as of 1994) had been ambushed and assassinated in what is called the Massacre of Cantaura, in the state of Anzoátegui. In May 1986, in what is called the Massacre of Yumare in the state of Yaracuy, nine political activists were captured and killed, and many of them tortured. The initial official version in all cases was that these individuals were guerrilla members killed in combat by security forces. 
Venezuela received relatively little international attention for its human rights situation at the time. As reports of the gross human rights violations taking place elsewhere at the continent slowly became known, the world's attention was focused on the brutal dictatorships in Chile, Argentina, Brazil and Uruguay in the southern cone, and Nicaragua, Guatemala and El Salvador further north. Approximately 30,000 people were killed during Argentina's “dirty war." In Chile, approximately 3000 were killed and 40,000 tortured under General Augusto Pinochet's dictatorship. In Guatemala, it is estimated that 200,000 people were killed, the majority from the indigenous population.

And indeed, the persecutions taking place in Venezuela were not as systematic, or on the same scale of the aforementioned countries. Besides, Venezuela was a formally elected democracy. Nevertheless, political persecution and human rights violations took place in an extensive manner, targeting mainly leftist leaders and activists, those associated with the communist party, the guerrilla, the student movement and community activism. Amnesty International's report from 1980 opens with the following statement:

During the year Amnesty International has been mainly concerned about allegations of arbitrary imprisonment and short-term detention, "disappearances", killings and torture by security forces. (Amnesty International 1980:170)

The state's persecution of political dissenters implied that leftist political activists had to operate clandestinely. Yet, they ran the risk of being identified and targeted. This is how Alfredo, an activist in 23 de Enero, recalls an event of his childhood, some 40 years back:

ALFREDO: I remember once when we were kids ... we had a communist flag hidden beyond the refrigerator ... this was after they banned the communist party, we had to hide such things ... outside our house, we were living over at Monte Piedad then, a group of adecos and copeyanos were gathered together with some police ... my little brother found the communist flag behind the refrigerator and ran out and past them waving the flag, split naked!! My mother yelled that I had to go after him, I ran after him and got him back home in the house ... but the police came to 
our house and beat up my father .... But then they let him go to the toilet ... he climbed out of the a small window and ran away as fast as he could and hid over there in the barrio ... the day after we were at school, down there in la Cañanda, and someone told us that the police was on its way ... you know they had been looking in the registers in the Ministry for Education, ta, ta, ta our names, the sons of [name removed], my father ... when we heard that we took off and ran as fast as we could up to el Mirador, we ran the whole hill...

ISELIN: Did they really come for you, you were just kids?

ALFREDO: They were looking for my father! It was a dictatorship; they came after communist and the radicals. They didn't want any leftist movement to surge.

The persecution of Alfredo's father was nothing unusual at the time (except that one must admire his little brother's boldness). We were sitting in his living room in his worn-down apartment in 23 de Enero when he told me this story. As he talked, he was scrambling through all his books and magazines trying to find a poster of the most well-know "martyrs" of that time-leftist radicals that had been killed by the police and army. Many of them came from 23 de Enero. It was Alfredo that showed me the Spanish version of the Amnesty International report that is referred to above: its cover brown and its pages yellow, worn by time. "I don't know how I managed not to get killed," he said. We had talked the whole afternoon about how the police and army treated people in the barrios, and leftist activist in particular, during the Fourth Republic. Kill first and ask afterwards. Torture. House raids. Violent repressions of manifestations. Illegal detention. As a member of MAS and inhabitant of the political hotbed 23 de Enero, Alfredo knew many of those who had felt the mano duro (hard hand) of the state. A cousin of his was beaten and hung by the arms in a shower at the police station for 24 hours. Alfredo himself was only gravely beaten once, with a metal stick when the police rounded up some people by the bloques in Monte Piedad. "The guys hit me three times over my behind," he said, pointing to his bottom.

But as I always carried my wallet and a notebook in my back pockets, it didn't hurt. Then they commanded us to run. I didn't want to run a coño, so they guy started to hit me on my back. People were watching and booing 
and throwing bottles from the bloques. The guy hit and hit until another officer yelled that he had to stop, that he would kill me. He stopped and I walked away and ran home. Some neighbors came running and yelled to my mum "Señora Alvarez, Señora Alvarez, they are killing your son over by the bloques." "No, no, he is here," my mum responded. I must have been 16,17 years old.

Many times, the victims were not even involved in politics; they were only in the wrong place at the wrong time. One young kid in the neighborhood was shot and killed because he ran down the stairs with a stapler in his hands, and a police officer who saw him thought that it was a gun and shot him dead. Another time, the police yelled to a man passing by that he should stop. But he was deaf-mute and didn't hear them so he continued walking. They killed him on the spot. I asked what the families could do in such cases. Alfredo shrugged as if saying "nothing."

One boy over there in the bloques had a goodbye party with his family and friends before he was going to enroll in the military cuartel—you know that they hung up lists sending the boys to there and there. They ran out of caña (liquor) and he ran down to the shop to buy some more. There he met some police officers who tried to rob him of the caña. They started to fight and the police dragged him down here to the local police station.

Alfredo pointed to the building down by the metro station that used to be a feared police station, but which now operated as the headquarter for the colectivo Coordinadora Simón Bolívar.

There he was beaten up. His relatives started to alert people and many came running to the police station gathering outside yelling that the boy should be set free. This often happened when someone was arrested. The police called for back-up forces. Somehow the boy managed to escape and they ran after him. The caught up with him in the stairs leading up to his house. $\mathrm{He}$ was shot in the back. They put a hood on him and carried him down to the jefatura. The next day, the newspaper reported that a hooded man had been shot dead while participating in an attack on the police station.

It was common that the police or security forces planted arms or drugs or dressed victims up as guerrillas or encapuchados (with hoods) in order to justify their killings. This way, it was difficult for the families to push their case, and the officers got to add a notch to their belt. "Like the false 
positives now recently in Colombia," Alfredo said. He was referring to the revelations about members of Colombian security forces who murdered campesinos and dressed them up as guerrilla members in order to cash the reward that the army had promised for "dead terrorists." "People hated the police here," Alfredo said. "It was above the Policía Metropolitana who did these things, they were like a mafia."

\section{EVERYDAY REPRESSION}

Everyday repression of the popular sectors was also commonplace. Here is a story as recounted by Juan Alberto, now a political activist and Chávez's supporter in his early 30s from Catia Parish:

This must have been in the early nineties because I remember that I was wearing the school uniform from the liceo (secondary school). I was on my way home when the bus was stopped by the police on the way up the hill. The police entered the bus and ordered all males to line up and show their ID card. I had forgotten my ID card at home, and the police said that I was arrested. I protested and said that they must see that I was wearing a school uniform, that I was just a school boy, but they just pushed me in the back of the van with the others, I think they rounded up 10 or 12 men there. First we were sent to the police station down in Catia, where they left us in the backyard. I remember that I had to take a piss so desperately that I couldn't think of anything else, I asked the police officer if I could take a piss, but he told me to shut up, otherwise I would be sent to a cell.

After a while came a van from the National Police, they were driving from station to station picking up detainees, and we were taken to the main police station in 23 de Enero. There we were put in a cell. We were ordered to line up and take off all belts and shoelaces and stuff like that, so we wouldn't hang ourselves. Then they gave all of us three beatings on the back with a flat baton. I had to take a piss so desperately that I didn't even feel the beatings. Then a police officer came in, he was drunk, and said that someone had said that we had a gift for him, and if he liked the gift, he would let us go. People scrambled to collect the money that they had, I had nothing of course, and handed it over to him. But he just tossed it to the floor, screaming that it was not enough. We were all poor so it wasn't much. I remember how the other men threw themselves over the money on the floor, fighting over how much each of them had put in.

We stayed in the cell that night; we must have been around 20 men in one cell. I had to sleep on the floor next to the toilet, I remember that I put 
on the hood in my sweater and tied it as tight as I could around my head, there were cockroaches everywhere running over me.

The next morning everyone in the cell put together some money and one of the good cops went out to buy us some bread and mortadela (cheap sandwich ham). The other men gave me some food as well, even though I had no money. Later that day they allowed us to take a phone call. I called my aunt Christina because she was the only one in the family that had a phone then. But she wasn't at home, I think I spoke with my little cousin Julio and told him to find my mum and tell him where I was. So I just waited and waited, thinking coño de su madre (shit), since there was no phone at home they would have to find a car and go up the hill to find my mum. It would take forever. Finally, late in the evening, I heard that my mum and my brother came. The police officer said that they would have to give him a bottle of whiskey if they wanted to have me freed. My brother got furious saying that he wasn't going to give him shit, I heard my mother yelling that I was underage and that it was illegal to have me there. Then another police officer came and intervened, he said that the other police officer who wanted whiskey was drunk and had been up drinking since last night. So eventually they let me go and we went home.

Arbitrary arrest of men was a quite common occurrence. Often the purpose was merely, as in the story above, to get bribes from detainees in exchange for their release. Sometimes, police officers rounded up all the young men that they could find. Those who couldn't prove that they were studying or working were sent off to the army, backed by a law against vagrancy. At other times, the police entered the barrios with the purpose of finding and eliminating personal foes or criminal elements. As Juan Alberto recalls it, police incursions in the poor neighborhood constituted a constant potential threat of violence:

When I was a kid it wasn't the fear of the malandros (street gangs/criminals) that stopped us from hanging out in the street, it was the risk that the police would come. Sometimes they came and just rounded up all the men who were there, or sometimes they came to look for someone specific and then it was shooting and shooting and no one was safe. I remember once they were looking for my neighbor Johnny who was living in front of me, we were friends when we were younger, but then he became a malandro .... I was standing on the roof of our house watching it ... the police came banging on his door, yelling "where is he, where is he," his girlfriend was standing on the floor in the patio (backyard) screaming and screaming ... the police stormed in and searched all the rooms, they found him in his bed, and they shot him dead right there in his bed. 
Both of these stories, as recalled by Juan Alberto, took place in the early 1990s. Stories like that of Juan Alberto and Alfredo are often recounted by popular sector inhabitants and activists as a manner of illustrating how everyday state violence during the Fourth Republic was carried out, creating a sense of being under permanent siege by a hostile state apparatus.

Simultaneously, the escalating political protests were increasingly met with violence during the 1990s. According to López and Parker, "one out of three nonviolent protests was repressed, with an elevated cost in human lives" during the government of Carlos Andrés Pérez (López et al. 2005:97). Repression of protests diminished during the subsequent Caldera presidency (1994-1999), when approximately one out of six protests was violently repressed. However, the state's antagonism toward the poor had already left a deep and collective open wound due to an event that took place a few years earlier, namely the Caracazo in 1989.

\section{El Caracazo}

People came down from the cerros (shantytown hills) and started to loot the shopping mall Propatria. ${ }^{7}$ The police came in masses and started to shoot. They gathered on the roof of the mall and shot indiscriminately up towards the cerro (shantytown hill). Many people were looting a department store some stories up in the mall. The police gathered in front of the door and shot people as they came running out. They shot them down like rabbits. I saw a lot of people lying around here dead. Afterwards they took the bodies and dumped them over at el Cementerio del Sur in the mass grave. That is why we still don't know how many people died.

Juan Alberto, 33 years old from Propatria. A young school boy at the time, he escaped his mom's house during el Caracazo in order to loot notebooks.

No event in Venezuela, perhaps with the exception of the 2002 coup against Chávez, is etched in people's minds as deeply as the Caracazo uprising. ${ }^{8}$ The riot started on February 27, 1989, and lasted several days. Probably the first IMF riot in the world, tens of thousands of people reacted spontaneously to the consequences of a new round of structural adjustment reforms (see Chap. 2). However, the reforms were just the last straw, as social misery and unrest had been growing for years. The distance between the governing elites and the impoverished masses had 
become so wide that the authorities never saw it coming. In the narratives of el Caracazo there is a strong sense of betrayal-not only because Carlos Andrés Pérez lied during his electoral campaign and imposed new IMF reforms once in office, but also because the use of indiscriminate violence against the poor population was so massive. El Caracazo made it clear that the illusion of a social contract between the poor and the rest of society was irrevocably compromised. From that moment on, the popular sectors become increasingly radicalized, which explains the massive support for the attempted coup led by Chávez in 1992. This, in turn, paved the way for the election of Chávez in 1998.

The slogan "el pueblo tiene hambre" [the people are hungry] was frequently scribbled on walls during el Caracazo (Coronil and Skurski 2006:110). Preceding the riots, the poor part of the population had seen their living conditions worsened over a period of several years. This was not only related to a general condition of unemployment and a deterioration of working conditions, education, health and other public services, but also to a situation of widespread hunger and malnutrition, where people were struggling to feed themselves and their children. Rosa illustrated the desperate situation that many people were facing like this:

Look, there was a time when people ate dog food here, a dog food called Perraina. They gave dog food to their children because it was cheap. And when the producers of the dog food realized that people bought it as food, they increased the prices! Imagine that! If you tell this to people, many will say that it was a lie. But I remember. Not everyone, but many people ate dog food.

In 1989, only 30 percent of Venezuelan households were economically capable of meeting their basic needs, that is, to purchase the stipulated basic food basket and additional necessities (Pedrazzini and Sanchez 1992:16). Research carried out at the time concluded that the calorie consumption in the barrios in Caracas dropped from $2327 \mathrm{kcal}$ per day in 1983 , to $1869 \mathrm{kcal}$ per day in 1989-far below an adult's estimated daily minimum intake. ${ }^{9}$ The consumption of proteins dropped in particular (Cavendes 1990:41, cited in Pedrazzini and Sanchez 1992:17). This is also consistent with what people have told me about their diet at the time. They basically survived on rice, some beans and arepa (cornflour bread). Meat was an uncommon luxury. This is how Juan Alberto recalls his childhood diet: 
ISELIN: JUAN ALBERTO:
So what did you eat?

Well, in the morning we normally just had a coffee. And for school we sometimes had a cold arepa or nothing. I remember how it felt like sitting on the school desk being so hungry that I couldn't think. I remember once that one of my class mates who had more money than us looked at my arepa and asked if I wanted to switch, he had one of those Yoko juices and a sweet bun filled with vanilla cream. I just threw him the arepa and grabbed his lunch pack and ran before he could change his mind.

When we got home from school, it was rice and beans for lunch. My grandma made food for all of us, all the siblings and my cousins who she was also taking care of at day time. She covered the floor with newspapers and put all of us there, we were sometimes as much as 12 kids, and then she gave all of us a plate of rice and some beans. I think she must have cooked like a kilo of rice each day. I didn't really eat meat until I was a teenager. If we sometimes had a piece of meat, it was the cheap ham, the mortadela. ${ }^{10}$ Or we killed one of our hens that we kept in the backyard and shared it among all of us. Or sometimes a can of sardines or tuna fish. But we usually ate rice and arepa, rice and arepa, and beans. I used to move the few black beans around at the plate as I ate, so that it would seem like there was more of them. In the evening it was arepa with margarine. I used to fill the arepa with rice if there was some left from the lunch, so it was more filling. Or sometimes there was nothing to eat in the evening.

ISELIN: And what did you do then?

JUAN ALBERTO: Then I went to bed hungry.

The Pérez government enacted some social policies in the form of direct monetary subsidies or assistance programs targeted toward the poorest in an attempt to mitigate the social crisis that was unfolding. However, 
according to my informants, these programs were poorly developed at best. One girl recalled that the relief provided through one of the government's food relief programs took the form of her school teacher sitting at his desk with a piece of ham, distributing small pieces of the meat among the students.

Moreover, the government's social policies only partially compensated for the abrupt deterioration of living conditions, as the traditional programs (health, education, and housing) also deteriorated (Lander and Fierro 1996:65). The government's social expenditure per capita in the 1989-1991 period was the lowest since 1968 (Lander and Fierro 1996:66). Diseases, thought to have been eliminated, reappeared, infant malnutrition increased, as did mortality and infant mortality (Lander and Fierro 1996:66). These worsening living conditions, coupled with an increasing rage against the political system and widespread state violence, help us understand the repressed rage that was unleashed with el Caracazo. The uprising was a perfect storm that had been brewing for a long time, and a rejection of the system that for a long time had increasingly proved itself to be corrupt, violent and hostile toward the poor majority which was paying the price for political decisions taken away from its spheres of participation. Rosa, after having described the years and months leading up to the Caracazo, said:

it was something ... something horrible, horrible, horrible all this that was taking place ... it is almost indescribable, I cannot say to you "look, this happened, this is what it felt like," it was like a torment of many things, of many emotions, of many things that had been repressed and people took to the streets to protest.

According to the late Fernando Coronil, el Caracazo was "the largest and most violently repressed revolt against austerity measures in Latin American history" (1997:376). The popular sector neighborhoods were swarmed with police and armed forces that shot and killed indiscriminately, riddled residential complexes with holes of machine gun fire, rolled into the communities with military tanks, and dragged activists out of their homes for execution (Ciccariello-Maher 2013:96). A report by the Relatives of Victims Committee (Comité de Familiares de Victimas) estimates that 97 percent of the victims were killed in their own homes (Ciccariello-Maher 2013:97). The number of people that were killed is 
still disputed - at the time, official estimates placed it at 300, while popular estimates put the number as high as 3000 casualties. The newspaper quickly stopped reporting on the number of causalities (Coronil and Skurski 2006:118) and the Pérez government sought to obstruct investigations in the aftermath of the massacre (Ciccariello-Maher 2013:96). People searched frantically for their loved ones in overfilled jails, hospitals and morgues. Decomposing bodies were piling up in the morgues, and the city ran out of coffins (Coronil and Skurski 2006:118). Soon thereafter, morgue workers told desperate family members that unidentified bodies had been driven away by trucks—in garbage bags. In 1990, a mass grave was opened in El Cementerio de Sur in Caracas, and 68 bodies wrapped in plastic bags were unearthed (Ciccariello-Maher 2013:97). This secluded spot in the cemetery is still vivid in people's mind and is known as El Nuevo Peste (the new plague).

While the riots in the rest of the country were quelled after three days, Caracas was in an upheaval for five days (Ciccariello-Maher 2013:97). Famed for its radical stance, 23 de Enero was particularly targeted by state forces. The bloques are, up to this day, riddled with bullet holes. The lack of concern in distinguishing between looters and non-looters, as well as women, children and the elderly, illustrates to what extent "the poor" had become a single adversary-one group identified as an enemy of the state. Ernesto, a long-time revolutionary who has lived in 23 de Enero all his life, recalls it like this:

ISELIN:

I remember that you told me once about the military tanks coming up to the square outside your house [in 23 de Enero].

ERNESTO: $\quad$ Yes, exactly, at the square.

ISELIN: When was this?

ERNESTO: This was like the 27, 28 [of February 1989], or I think March 1, because it was difficult for them at first to get into 23 de Enero. And of course, they were busy elsewhere, with other disturbances ... but as they quelled those disturbances, 23 de Enero was what was left ... so they paraded towards 23 de Enero in their tanks, the National Guard in particular, and of course some units from the army ... they came to bloque 26 , bloque 24 and 25 , to 
the central zone of 23 de Enero, like bloque 1 ... to the area of Monte Piedad, bloque 5 , bloque 7 , bloque 6 , they were ... floor 12 and upwards were virtually bullet-holed indiscriminately, including the roof and everything ... people were terrified, the children, the elderly .... and of course afterwards no one apologized or anything...

I'd say that the psychological damage that they did to those people, well ... no one can imagine what could have happened ... some people died from a heart attack ... of course, imagine a situation like that?

And of course, afterwards reports were made, human rights and all that, but at the time these things didn't work very well here, and it wasn't even possible to put forward a serious denouncement, because if you were detected, you were converted into a target for any of these [state] bodies and any of these functionaries could carry out reprisals against you or anyone in your family or your friends ... so it was necessary to be very careful.

Even after el Caracazo, the government didn't make any concessions to the demands of the poor sectors (Lopez et al. 2002:17). Public popular protests continued and increased. According to the Venezuelan NGO Provea, a total of 7092 public protests took place between 1989 and 1999, constituting an average of two protests per day (Lopez et al. 2002:9). The number of protests peaked between 1992 and 1994, which correspond to the years of Chávez's failed coup (1992) and of Carlos Andrés Pérez's conviction for corruption (1993) (Lopez et al. 2002:9, Table 1).

\section{Oil in the Fourth Republic}

What took place during the 1980s and 1990s was not only the breakdown of a political and economic model; it was also the breakdown of an idea about a nation. As Derham (2010) terms it, the Venezuelan state increasingly revealed itself to be an "antagonistic state" for large sectors of the population. A central part of this antagonism consisted of state violence 
combined with a sense of being forced to shoulder the price for the elite's mismanagement and usurpation of national wealth.

During my field interviews, I often asked middle-aged or elderly people what they thought about oil during the Puntofijo era. To my surprise at first, almost everyone responded that they didn't think about it, or that they didn't know much about it. However, it soon dawned on me that this professed lack of consciousness about oil to a large extent was a reflection of the schism between "the two Venezuelas": that of the middle and upper classes imagining themselves in the core of and benefiting from the oil state, and that of the popular sectors who had no means to partake in the symbolic and material manifestations of its riches. As one elderly woman said: "oil didn't concern us, oil was for the oil people."

If we remember Coronil's words about the little that we know about how subaltern lives were lived in the shadows of the Magical State, it is my belief, through numerous conversations, that people were above all concerned with mitigating life's innumerable challenges in their immediate life worlds. However, that does not mean that the grandiose imagery of the Magical State that he describes was not present though the everpresent promises and political spectacles that the poor were also exposed to. Indeed, as Ewell indicates (Ewell 1984:193) and as we will address more in depth later on, Carlos Andrés Pérez's golden period in the 1970s in particular conjured an imagery of prosperity being just around the corner, also for the poor. However, in spite of these expectations and the Venezuelan state's dazzling spectacles, people's tangible experiences with the state were above all characterized by marginalization and oppression. While some experienced a growing frustration leading to an enormous anger with the whole system (as evidenced by the frequent protests during the 1980s and 1990s), others again described themselves as apathic during these years. They had no interest in or concern for politics. It belonged to the realm of "the others."

However, historical memory is a malleable imaginative horizon. As Schwartz notes, "the way ordinary people conceive the past, reflects the concerns of the present" (Schwartz 1997:470, cited in Auyero 2001:183). And I believe that we can safely assume that knowledge about oil was present at some level for most people, even if they felt that it didn't concern them. However, if we do contend that our focus in the present shapes our memories of the past, it follows that Chávez's promise to redistribute oil gave new meaning to their memories of the Fourth Republic. It was through Chávez's political message that many people internalized that 
they actually, as citizens of the oil-rich nation-state Venezuela, were coproprietors in the nation's wealth. Through this new sense of collective entitlement, collective memory-making of the "absence of oil" gained a strong imaginative and emotional power. Following Tilly's notion of collective memories having structuring capabilities (Tilly 1994a:244, cited in Auyero 2001:184), Chávez's call for popular involvement in the state's effort to pay its historical debt to the poor through redistributing the nation's oil wealth provided them with a deep sense of historical revindication.

This sense of continuity between their collective deprivation in the past and their collective struggle in the present was a strong impetus for exploring and shaping new venues for grassroots activism. We will return to this theme in Chap. 5.

In this chapter, I have addressed how popular sector support for the Chávez government built on historical trajectories of popular mobilization dating decades back, and how people recall their experiences of being marginalized and oppressed during the Puntofijo-era. In the following chapter, I will explore the structural and spatial dimension of Venezuela's class division, and how Chávez's rise to power, and the political empowerment of previously marginalized groups, produced a deep confrontation in Venezuelan society. I want to start by inviting the reader on a journey where the oil money that never reached the barrios did flow; to the wealthy districts of Eastern Caracas.

\section{Notes}

1. Unwillingness on the part of Venezuelan politicians to assume responsibility for their actions has translated into the colloquial expression "yonofui" [yo-no-fui, it wasn't me].

2. Elsewhere, the differences between the neopopulism of Hugo Chávez and Alberto Fujimore, often referred to as prime examples of the resurgence of Latin American populism, have been analyzed in depth (Ellner 2003; Roberts 2006).

3. Here I must be quick to note that I am mainly thinking of left-wing populism in Latin America, as right-wing populism as we are seeing in contemporary Europe and the US should be treated separately and as a contextually different phenomenon. 
4. MIR was founded in April 1960 (Fernandes 2010:48) by members of Acción Democrática who left the party in protest against its lack of radicalism.

5. Urbanizaciones is the Venezuelan term for middle- and upper-class neighborhoods dominated by gated condominiums.

6. Ali Primera's music was declared national patrimony by the Venezuelan government in 2005. This is the author's translation from Spanish of the original lyrics which can be found on http://www.musica.com/letras. asp?letra $=1389248$.

7. A huge shopping mall in Catia called Centro Comercial Propatria, which is still operating.

8. El Caracazo is also sometimes called El Sacudón (from saqueo which translates into looting).

9. The daily estimated consumption need in Norway is about $2150 \mathrm{kcal} /$ day for an adult inactive woman and about $2600 \mathrm{kcal} /$ day for an adult inactive man (Smith Sørhøy and Heir n.d.). It is reasonable to assume that the great majority of adults in the popular sectors in Caracas at the time were carrying out hard physical labor or otherwise had a significant level of physical activity, such as manual household labor, carrying water or walking long distances in the absence of adequate and affordable public transport.

10. Mortadela is a cheap ham sandwich, similar to a bologna sandwich.

\section{BiBLIOGRAPHY}

Alvarez, Sonia E., Evelyn Dagnino, and Arturo Escobar. 1998. Cultures of Politics, Politics of Cultures: Re-Visioning Latin American Social Movements. Boulder: Westview Press.

Amnesty International. 1980. Amnesty International Annual Report 1980. London: Amnesty International Publications. https://www.amnesty.org/en/ documents/poll0/0003/1980/en/. Accessed February 20, 2017.

Arditi, Benjamin. 2007. Politics on the Edges of Liberalism. Difference, Populism, Revolution, Agitation. Edinburgh: Edinburgh University Press.

Auyero, Javier. 2001. Poor People's Politics. Peronist Survival Networks and the Legacy of Evita. Durham and London: Duke University Press.

Canache, Damarys. 2002. From Bullets to Ballots: The Emergence of Popular Support for Hugo Chavez. Latin American Politics and Society 44 (1): 69-90.

Ciccariello-Maher, George. 2013. We Created Chávez: A People's History of the Venezuelan Revolution. Durham and London: Duke University Press.

Coronil, Fernando. 1997. The Magical State: Nature, Money, and Modernity in Venezuela. Chicago: University of Chicago Press. 
Coronil, Fernando, and Julie Skurski. 2006. States of Violence. Ann Arbor: University of Michigan Press.

Corrales, Javier. 2001. Strong Societies, Weak Parties: Regime Change in Cuba and Venezuela in the 1950s and Today. Latin American Politics and Society 43 (2): $81-113$.

Derham, Michael. 2010. Politics in Venezuela. Explaining Hugo Chávez. Oxford, Bern, Berlin, Bruxelles, Frankfurt am Main, New York, Wien: Peter Lang.

Elizalde, Rosa Miriam, and Luis Báez. 2004. Chávez Nuestro. Havana: Casa Editora Abril.

Ellner, Steve. 2003. The Contrasting Variants of the Populism of Hugo Chávez and Alberto Fujimori. Journal of Latin American Studies 35 (1): 139-162.

Escobar, Arturo, and Sonia Álvarez. 1992. The Making of Social Movements in Latin America. Identity, Strategy and Democracy. Boulder, San Francisco and Oxford: Westview Press.

Ewell, Judith. 1984. Venezuela. A Century of Change. London: C. Hurst \& Company.

Fernandes, Sujatha. 2010. Who Can Stop the Drums? Urban Social Movements in Chávez' Venezuela. Durham and London: Duke University Press.

Geertz, Clifford. 1973. The Interpretation of Cultures. New York: Basic Books, Inc.

Jansen, Robert. 2011. Populist Mobilization: A New Theoretical Approach to Populism. Sociological Theory 29 (75): 75-96.

Knight, Alan. 1998. Populism and Neo-populism in Latin America, Especially Mexico. Journal of Latin American Studies 30 (2):223-248.

Lander, Edgardo, and Luis A. Fierro. 1996. The Impact of Neoliberal Adjustment in Venezuela, 1989-1993. Latin American Perspectives 23 (3): 50-73.

López, Margarita M., David Smilde, and Keta Stephany. 2002 [1999]. Protesta y culturaen Venezuela. Los Marcos de Acción Colectiva en 1999. Caracas: FACESUCV, CENDES, FONACIT.

López, Margarita M., Luis Lander, and Dick Parker. 2005. Popular Protest in Venezuela: Novelties and Continuities. Latin American Perspectives 32 (2): 92-108.

Pedrazzini, Yves, and Sanchez R. Magaly. 1992. Malandros, Bandas y Niños de la Calle. Cultura de Urgencia en la Metropoli Latinoamericana. Valencia and Caracas: Vadell Hermanos Editorial.

Rivero Santos, Angelo. 1995. Neighborhood Organizations in Venezuela: "Los Vecinos" Voice Their Dissent. Yearbook: Conference of Latin American Geographers 21: 1-12.

Roberts, Kenneth. 2006. Populism, Political Conflict, and Grass-Roots Organization in Latin America. Comparative Politics 38 (2): 127-148.

Sørhøy, Marit Smith, and Wenche Heir. n.d. Energi og energibehov. Digitale læremidler for videregående opplæring. NDLA. http://ndla.no/nb/ node/61375. Accessed February 20, 2017. 
Strønen, Iselin Åsedotter. 2006. "For Us This Is Utopia Coming True.” Venezuela's Bolivarian Revolution and Popular Movements in a Caracas Barrio. MA thesis, Department for Social Anthropology, University of Bergen.

Weyland, Kurt. 1999. Neoliberal Populism in Latin America and Eastern Europe. Comparative Politics 31 (4): 379-401. 2001. Clarifying a Contested Concept: Populism in the Study of Latin American Politics. Comparative Politics 34 (1): 1-22.

Open Access This chapter is distributed under the terms of the Creative Commons Attribution 4.0 International License (http://creativecommons.org/ licenses $/$ by $/ 4.0 /$ ), which permits use, duplication, adaptation, distribution and reproduction in any medium or format, as long as you give appropriate credit to the original author(s) and the source, provide a link to the Creative Commons license and indicate if changes were made.

The images or other third party material in this chapter are included in the chapter's Creative Commons license, unless indicated otherwise in a credit line to the material. If material is not included in the chapter's Creative Commons license and your intended use is not permitted by statutory regulation or exceeds the permitted use, you will need to obtain permission directly from the copyright holder.

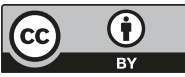

